\title{
A Psychoanalytic Perspective on an Interview with an Irish Republican Prisoner
}

\section{by Barry Geoghegan}

\section{(cc) $\mathrm{EY}$}

This work is licensed under a Creative Commons Attribution 3.0 License.

\begin{abstract}
Taking an interview with an Irish Republican Prisoner imprisoned at the Curragh Internment Camp for the duration of the Second World War, the principle objective of this analysis is to demonstrate that psychoanalysis as a depth psychology, can transcend political/ideological considerations in respect of the justice or otherwise of a cause, or moral opprobrium over the tactics employed. Arguing that the context of every conflict is historically unique and using the notions of national identity and the intergenerational transmission of guilt, the analysis demonstrates that the psychic position of the individual terrorist is not necessarily pathological.
\end{abstract}

- he tendency amongst clinical psychoanalysts according to K.R. Eissler, is 'to look at a patient engaging in revolutionary activities or believing in revolutionary persuasion as acting out' (Eissler, 2002, p132). In the personality pathology theory of terrorism, the violent or aggressive 'symptomology' of the individual is extrapolated to this wider cohort, with the principle protagonist Jerrold Post having it that, for 'the paranoid individual seeking a "legitimate" channel for his aggression, the terrorist group provides an ideal venue. Because terrorists bring their personalities with them when they enter the group, the same personality distortions that led to their conflict and isolation in society will express themselves in the group' (Post, 1986, p 223).

This terrorist paranoia is considered by Post to be 'primitive form of narcissistic pathology', with narcissistic entitlement inevitably leading to frustration and retaliatory rage (Post, 2015, p 10). The initial narcissistic injury is seen as deriving from early faulty or traumatogenic object relating, in particular from cold or unempathetic care givers, and in respect of terrorism as Shmuel Erlich points out, it is the 'currently widely held psychoanalytic stance' (Erlich, 2003, p 148). Through Heinz Kohut's formulation of a mirroring 'narcissistic transference', Post posits a conceptualisation of the terrorist as being in a needy charismatic leader-follower relationship (Post, 2015, 74). The development of the charismatic leader's pathological 'grandiose self' is as Post describes Otto Kernberg's notion, that of extreme grandiosity 'associated with primitive and defective superego formation', potentially leading to the dangerous personality disorder of 'malignant narcissism' (Post, 1993, p 114). Gathering their followers from a 'disadvantaged or traumatized social group', the rejected and traumatised the leadership of the terrorist group according to Kernberg, often present with the 'syndrome of malignant narcissism' (Kernberg, 2003, p 958).

The purpose of this paper is to provide a culturally oriented and hopefully more nuanced psychohistorical alternative to the simple extrapolation of a putative individual narcissistic clinical pathology, in explaining the rationale of the insurgent or terrorist group. The paper proposes that instead of the acting out an individual narcissistic injury through the terrorist group, the individuals in that group may actually be rational actors seeking to assuage the narcissistic injuries inflicted upon a culture. These individuals are not necessarily 


\section{Journal of Terrorism Research}

individually narcissistically injured, traumatised and marginalised, but those who actually have a greatly heightened sense of belongingness and take it upon themselves to carry the burden of the narcissistically injured culture as a function of their own identities, actively seeking to lance the festering national wound. In this endeavour and in particular the phenomenological aspects, I have been greatly assisted by John Hunt who at 95 is the last of the old guard Republicans interned in the Curragh internment camp for the duration of the Second World War.

\section{Background}

In early 1939, the IRA (Irish Republican Army) had launched a bombing campaign on mainland Britain, with Irish President Éamon De Valera's government regarding these IRA attacks against Britain as posing a threat to the Irish state itself. Recently uncovered archive material demonstrates that De Valera's belief was, that 'if his country was seen as a threat, London might decide to invade' (Thomson, BBC, 2011). Knowing according to Mike Thomson, that the 'hard rump of Republicans would never countenance being allied to the "old enemy" Britain, and that such an alliance could push Ireland into another bloody civil war', De Valera was anxious to maintain Irish neutrality in the forthcoming war (ibid).

Republicanism was as Jill Uris and Leon Uris put it, 'deep-seated and an alter ego for the masses', and as such there was difficulty in securing convictions against IRA members (Uris and Uris, 1977, p 155). So that under 'Emergency Powers Act of 1939 and the Offences Against the State (Amendment) Act of 1940' enacted by De Valera, civil liberties were suspended and internments without charge were introduced (Maguire, 2004, p 1). The men detained were held in what Uris and Uris describe as the notorious Curragh internment camp, where the 'horrors of imprisonment became legendary', with the IRA keeping up 'hunger strikes, riots, and daring escapes' (Uris and Uris, 1977, p 156). John, as documented in Uinseann MacEoin's book_The IRA in the twilight years: 1923-1948 (1997), was for six years incarcerated in the Curragh.

\section{National Trauma, Identity and Joining the Cause.}

John describes the process by which a historical sense of grievance became imbued in his nationalist ideology in a societal environment where news and information was passed on by word of mouth;

John: 'So, people like me that came from a rural village in Ireland and, knew of the history that was being told in the small village. At the fireside, that is where I learned my history ...

But you always have something about the famine. It was a living thing. Now, I believe this, that, that was genocide. They wanted to spoil the Irish race. The Irish race had to be done away with'

(Personal Communication, John Hunt, 2014).

Through this osmotic bucolic process, John develops his historical sensibility as part of his identity. History and particularly the trauma of the Irish Famine which took place between 1845 and 1852, is still for John a 'living thing' (Personal Communication, John Hunt, 2014). This represents what Vamik Volkan terms the 'transgenerational transmission' of trauma, a process involving 'the depositing of an already formed self or object image into the developing self representation of a child under the premise that there it can be kept safe and the resolution of the conflict with which it is associated can be postponed until a future time. The "deposited image" then becomes like a psychological gene that influences the child's identity' (Volkan, 1998, pp 3-4). Such identity for Erik Erikson is primarily a social construct representing a mutual relation in that it connotes both a persistent sameness within oneself (self-sameness) and a persistent sharing of some kind of 


\section{Journal of Terrorism Research}

essential character with others (Erikson, 1960, p 38).

In a form of mourning process, the trauma representing a real or imagined disappointment in an original object attachment shatters the object relationship, and the result as Freud has it, is 'not the normal one of a withdrawal of the libido from this object and a displacement of it on to a new one, but something different ... an object-loss was transformed into an ego-loss and the conflict between the ego and the loved person into a cleavage between the critical activity of the ego and the ego as altered by identification ... The narcissistic identification with the object then becomes a substitute for the erotic cathexis, the result of which is that in spite of the conflict with the loved person the love-relation need not be given up' (Freud, 1917, XIV, p 249).

The trauma to the nation in effect becomes a narcissistic aspect of the collective ego, and it is clung to as a badge of honour reflecting a sense of national identification. Thus the object introjected that is to say the Irish sense of loss, is transmuted onto the individual ego in a narcissistic identification. As John was 'bred to believe, that there should not be a foreign flag in any part of that island', the presence of one is akin to an epigenetically transmitted narcissistic wound which must be dealt with as manifesting a cultural stain on the national and no individual psyche (Personal Communication, John Hunt, 2014). John's core identity is then narcissistically bound to his mourned object, he becomes effectively a representation of Ireland indeed his very being is Ireland.

Describing this formative psychic 'breeding' process of 'introjection, identification, and identity formation', Erikson has it that the 'mechanism of introjection (the primitive "incorporation" of another's image) depends for its integration on the satisfactory mutuality between the mothering adult(s) and the mothered child. Only the experience of such initial mutuality provides a safe pole of self-feeling from which the child can reach out for the other pole: his first love "objects." The fate of childhood identifications, in turn, depends on the Child's satisfactory interaction with trustworthy representatives of a meaningful hierarchy of roles as provided by the generations living together in some form of family' (Erikson, 1968, p 159).

Commenting on Freud's own soul searching in relation to his Jewish identity, Erikson remarks that 'identity points to an individual's link with the unique values, fostered by a unique history of his people. Yet, it also relates to the cornerstone of this individual's unique development ... It is this identity of something in the individual's core, with an essential aspect of a group's inner coherence, which is under consideration here: for the young individual must learn to be most himself where he means most to others-those others, to be sure, who have come to mean most to him' (Erikson, 1960, p 38).

Volkan posits that a 'chosen trauma' 'refers to the mental representation of an event that has caused a large group to face drastic losses, feel helpless and victimized by another group, and share a humiliating injury ... I believe that it reflects a group's unconscious "choice" to add a past generation's mental representation of an event to its own identity ... A chosen trauma is linked to the past generation's inability to mourn losses after experiencing a shared traumatic event, and indicates the group's failure to reverse narcissistic injury and humiliation inflicted by another large group, usually a neighbor' (Volkan, 1998, p 4, emphasis in the original). If the succeeding generation is unable to successfully 'mourn the loss or reverse the humiliation, it will in turn deposit this mental representation in the next generation' (ibid). The chosen trauma becomes then, woven into the fabric of ethnic group's identity.

Basing his analysis on Freud's notion of adult mourning in his Mourning and Melancholia (Freud, 1917, XIV), and extrapolating from a clinical to a psychohistorical perspective, the traumatised society for Volkan, behaves like 'an individual who suffers from perennial mourning' (Volkan, 2007, p 5). In Freud's theory 'mourning is regularly the reaction to the loss of a loved person, or to the loss of some abstraction which has 


\section{Journal of Terrorism Research}

taken the place of one, such as one's country, liberty, an ideal, and so on. In some people the same influences produce melancholia instead of mourning and we consequently suspect them of a pathological disposition' (Freud, 1917, XIV, p 243)

There is then something pathological in this melancholic aspect Irish society in failing to successfully resolve the mourning process deriving from the trauma of the Great Famine. The distinguishing mental features of melancholia are for Freud a 'profoundly painful dejection, cessation of interest in the outside world, loss of the capacity to love, inhibition of all activity, and a lowering of the self-regarding feelings to a degree that finds utterance in self-reproaches and self-revilings, and culminates in a delusional expectation of punishment' (Freud, 1917, XIV, p 244). This process need not though result in merely sullen depression but on the contrary according to Freud, such melancholic's 'make the greatest nuisance of themselves, and always seem as though they felt slighted and had been treated with great injustice. All this is possible only because the reactions expressed in their behaviour still proceed from a mental constellation of revolt, which has then, by a certain process, passed over into the crushed state of melancholia' (ibid, p 248).

Psychoanalytic enquiry has demonstrated according to Volkan, that this transgenerational transmission of trauma induced melancholia, is more than, just 'a child mimicking the behavior of parents, or developing his or her own ideas based upon the stories told by the older generation. It is the end result of mostly unconscious psychological processes that influence the child's identity and unconsciously give the child certain tasks' (Volkan, 1998, p 4). Similarly, the collective group experience is more than the sum total of the 'many individuals of that groups sharing similar symptoms of Post-traumatic Stress Disorder, utilizing similar defense mechanisms, or exhibiting symptoms of similar psychological problems. Such traumatic events affect all those under the ethnic or national tent, and all are subjected to societal processes, many of them unconscious, in response' (Volkan, 1998, p 4). Taking on their own specific characteristics, the transgenerational transmissions of trauma are then collective phenomena, which reflect societal processes or indeed political ideologies.

Particular individuals though, John clearly being a case in point, feel the weight of this national seemingly epigenetically transmitted melancholia bearing down on them more acutely than on others, with a psychic need to take upon themselves the reparations needed to grieve, and thus resolve the mourning process. The loss and mourning for an ambivalently loved object gives rise in Melanie Klein's schema, for a concern to put matters right which she terms 'reparation' (Klein, 1987). The reparative process involves not only restoring the obsessively mourned object, but in shoring up the psyche of the individual himself, and for Klein 'it is not only an object about whom guilt is experienced but also parts of the self which the subject is driven to repair or restore' (Klein, 1987, p 187).

If the sense of guilt is though overly strong according Klein, 'this identification may lead to an entirely self sacrificing attitude which is very much to the child's disadvantage. It is well known that a child who has been brought up by a mother who showers love on him and expects nothing in return often becomes a selfish person' (Klein, 2002, p 318). The reparative self-sacrifice is then repaid by the object as represented by the Irish State, by furthering its own 'selfish' geopolitical concerns. This resulted in the imprisonment of John and his IRA colleagues who reflected a projective mirror of the object's guilt and humiliation, as the government was comprised entirely of former IRA members. 


\section{Journal of Terrorism Research}

John: 'rebelled against the authority because the authority ...

To keep the order, the law and order, that that state or foreign government wanted ... And they're Irishmen. And as long as they keep backing that foreign power, I'll keep fighting them'.

(Personal Communication, John Hunt, 2014).

Unlike for Volkan who sees resurrected trauma as being deployed as an agitating tool by malignantly narcissistic leaders, the Irish Famine for John was an always already living thing, a function of his ego identity. From his personal perspective, John eschews the notion of this trauma as an incitement to dehumanise a hated 'Other'. John has it rather that, 'they're human beings the same as I am', and that he has 'no quarrel with the English people', only an English Government that he believes has oppressed his ancestors and was in league in the immediate pre-war period as the newly released documents actually confirm, with the Irish Government (Personal Communication, John Hunt, 2014; Thomson, 2011).

\section{Relating to the Wider Context of Terrorism}

Terrorists according to Post, draw their membership 'from marginal, isolated, and inadequate individuals from troubled families, so that for many, belonging to the terrorist group is the first time they have truly belonged to any group' (Post, 1986, p 211, emphasis in the original). John though was born into a reasonably prosperous professional and merchant family well integrated and respected in his locality. John's identity is the wider but actually for him the more visceral sense of being Irish;

John: 'That's, that's my core and my identity' ... It's, it is a love ...

It's a real thing to me... I live it every day

(Personal Communication, John Hunt, 2014).

Very confident and assured in this personal and national identity, John does not seek to shore it up by group affiliation indeed that the group must reflect his identity and national ideology;

John: 'If there is an organization let them be called the IRA, let them be called anything they like. If they're for the good of my country. If they, if their ideas are the same as mine, I am with them. I am with them'

(Personal Communication, John Hunt, 2014).

Rather than the crudely ethnic enmity projected out as described by Volkan, who has it that the terrorist's 'targets of his violence are symbolized as unwanted and dangerous elements that originated from his internal world', John's enemy is the ambivalent institutional manifestation of his own introjected object, Ireland and indeed the Irish (Volkan, 1998, p 162; Robins and Post, 1997). The conflict he is engaged in could be seen in fact, as an attempt at repairing this internal ambivalence of the transgenerationally transmitted humiliation and guilt which is at the same time the source of his core identity and self worth. Whilst an extremely devout Catholic, John is at pains to point out that he bore no sectarian animosity, having it that 'my best friend was a Protestant and he was executed' (Personal Communication, John Hunt, 2014).

The notion deployed by Volkan of a dichotomous borderline conceptualisation of splitting and projective ethnic enmity is not only inherently reductive, but actually subverts by subsuming the ideological complexity of these conflicts (Volkan 1998). Similarly Post's notion of the terrorist group's borderline splitting off the all bad and hated aspects of its collective group self, and projecting them onto the enemy, does not reverse engineer to reflect a similar individual developmental process or outcomes (Robins and Post, 1997). Belying 
the essential borderline symptomatic pattern of unstable and intense relationships which Post associates with the traumatic psychic injury and the splitting and projective identification that delineates his terrorist cohort, John was happily married to the same woman for some seventy years, and he rejects any association with the borderline traits of impulsivity, addiction and associated criminality, but does not deny its existence in his movement (Post 2007).

John: 'I don't, I'm not a dope addict and I'm not a drunk. I am an ordinary, honest, living person.

Who would like, to cause no problem to any individual ...

But then you always have the opportunist who will come in and create that problem which will create a far, a bad impression on the rest of Ireland. I'm not saying, every man in jail for the republic is that. But you have characters that, that sell dope'.

(Personal Communication, John Hunt, 2014)

In so far as he 'followed' leaders, they represented a tool for John to address the ambivalences of his ego identity. John emphatically eschews the notion that he had been inspired by his leaders or followed them because of their charisma;

John: 'I didn't follow anybody.

They were a part of the same history and the same culture I was ....

they shared my philosophy'.

(Personal Communication, John Hunt, 2014).

John was not then one of what Post describes as 'alienated, frustrated individuals' drawn in by the charismatic leader (Post, 2005, p 8). He was pulled into a conflict as a means of making reparations with his introjected object, his 'father' (Ireland);

John: 'I never thought the world against me ...

No not one was not against me. The people who took my father were against me ... And I would want to die until I got that father back'

(Personal Communication, John Hunt, 2014).

Effectively a prisoner of conscience, John's experience does not reflect Post's notion of the lock and key fit between the mirror-hungry personality of the charismatic leader and the ideal-hungry personality of the follower (Post, 2004). There was though a traumatising catalyst for his career as a rebel, however it happened not to John but a cousin of his;

John: 'Three miles from me there was, four men arrested, sitting on a bridge, and the black and tans [a specially recruited British force, notorious for its ill discipline] come in, they arrested the four men.

They put them, they took them to the other side of the ditch, and off of the road and they shot three of them and one man got away... They killed them and brutally murdered them ... And the, one of these people was a cousin of mine'

(Personal Communication, John Hunt, 2014).

John's was not then a personally traumatic event of narcissistic wounding as described by Volkan analysis. John claims to have had a very happy childhood and loving relationship with his parents so he does not appear to have been narcissistically wounded as per Post's early traumatogenic object relating formulation (Volkan, 1998; Post 1986). John's reaction to the incident would though seem to relate to a desire for revenge, 


\section{Journal of Terrorism Research}

as reflecting the darker side of a sense of injustice, recognised according to David Silke, to be 'for most terrorists a key motivation for joining a terrorist organisation' (Silke, 2003, p 39).

This desire for revenge is again not necessarily pathological per se, because as Cota-McKinley et al's research shows, that in Western culture revenge 'fulfils a wide variety of goals, including righting perceived injustice, restoring the self-worth of the vengeful individual, and deterring future injustice' (Cota-Mckinley et al, 2001, p 344). Revenge is also tied according to Cota- Mckinley et al, to the self worth of the individual, so that frequently it is individuals with little power who 'seek revenge against powerful adversaries even though the action has overwhelming costs' (ibid). Indeed terrorism is effectively the tactic of the weak deployed against the strong.

Addressing Post's central tenet that the 'cause is not the cause ... individuals become terrorists in order to join terrorist groups and commit acts of terrorism', John's story categorically rejects (Post, 1998, p 35, emphasis in the original);

John: 'The real man is not doing it for self interests.

He's doing it for a cause that he thinks is just.

What is a cause? A cause is a problem.

A foreign power in my country'

(Personal Communication, John Hunt, 2014).

Whatever other particular and personal psychic impulsions John may have had, the decision to dedicate his life and to an ideal and the consequent disruption of his life was a momentous one;

John: 'My social life was interrupted by a foreign power ...

And as long as there's a foreign flag in Ireland, I will fight until the day I die to get rid of that ...

I wouldn't, you wouldn't call it happiness... That I took this stand in life ... But I, I took it as a natural event ... Of course, I am, very proud of it ...

When a man lays down his life for his principles, there must be something in it'

(Personal Communication, John Hunt, 2014).

\section{Conclusion}

For Jerrold Post and the personality pathology theory of terrorism 'political terrorists are driven to commit acts of violence as a consequence of psychological forces, and that their special psycho-logic is constructed to rationalize acts they are psychologically compelled to commit' (Post, 1998, p 25, emphasis in the original). Normatively locating grievance and its outcome within the psyche of the 'Other', has the effect of enlisting psychoanalytic conceptualisations in support of one particular side in a politico/ideological conflict. As Raymond Corrado argues, political terrorists are then seen as engaging in gratuitous violence, which reveals psychopathological rather than socio-political' causes (Corrado, 1981, p 295). The policy consequences are that if terrorists are pathological, 'their political demands can be ignored and the strategic focus will be overwhelmingly a military response. If terrorists are political idealists, then it raises the possibility that complex political and social issues must be addressed by governmental policy' (Corrado, 1981, p 293).

Although the personality pathology model is the dominant psychoanalytic paradigm in explaining political violence, there is though no reason in particularly Freudian depth psychology, why either social upheaval or 
individual participation in it, should be regarded as normatively pathological. The culture wide melancholia induced by the Great Famine was reflected in a universal nationalist aspiration, so that individuals acting upon that sentiment could not in Freud's terms be regarded as individually pathological because 'for an individual neurosis we take as our starting-point the contrast that distinguishes the patient from his environment, which is assumed to "normal". For a group all of whose members are affected by one and the same disorder no such background could exist' (Freud, 1930, XXI, 144).

Similarly, such revolutionary activity may be viewed as psychohistorical evolution as with, in Freud's terms, 'victors and vanquished who turn into masters and slaves. The justice of the community then becomes an expression of the unequal degrees of power...the oppressed members of the group make constant efforts to obtain more power...from unequal justice to justice for all... a solution by violence, ending in the establishment of a fresh rule of law' (Freud and Einstein, 1933, XXII, p 206). Hegemonic normative forces induce psychic crises, with authoritarian regimes Nancy Caro Hollander argues, splitting the world 'into good and evil-Western Civilization vs. "subversion;" the projection of everything bad onto a hated object (the "subversive") with the consequent need to control it for fear of being controlled by it' (Caro Hollander, 2006, p 4). Revolutionary violence could then as Caro Hollander claims, derive from the resultant trauma, deprivation and frustration, with 'groups seeking a radical change in the social order, often based on attitudes of love, concern, and responsibility for others' (ibid, p 3).

The principle objective of this paper has been to demonstrate that psychoanalysis as a depth psychology, can transcend political/ideological considerations in respect of the justice or otherwise of a cause, or any overlapping moral opprobrium over the tactics employed (i.e. terrorism). The aim has been to provide a psychoanalytic analysis relating to notions of identity individual and national as they affect the individual's psyche and the individual's psychic responses to national trauma and conflict.

\section{About the author}

Barry Geoghegan is a PhD student at the Centre for Psychoanalytic Research, Middlesex University.

\section{References}

Coogan, T. (1993). The IRA: a history, Niwot, Colorado: Roberts Rinehart Publishers.

Corrado, R. (1981) 'A Critique of the Mental Disorder Perspective of Political

Terrorism', International Journal of Law and Psychiatry, Vol.4, pp, 293-309.

Cota-McKinley, A., Woody, W. and Bell, P. (2001) 'Vengeance: Effects of Gender, Age, and Religious Background', Aggressive Behaviour, Vol: 27, pp 343-350.

Eissler, K. (2002) 'On Hatred: With Comments on the Revolutionary, the Saint, and the Terrorist' in Covington, C., Williams, P., Arundale, J. and Knox, J. (Eds), Terrorism and War: Unconscious Dynamics of Political Violence, London, Karnac.

Erikson, E. (1960) 'The Problem of Ego Identity' in Stein, M., Vidich, J. and White, D. Eds, Identity and Anxiety: Survival of the Person in Mass Society, Illinois, The Free Press of Glencoe.

Erikson, E. (1968) Identity: Youth and Crisis, London, Faber and Faber.

Freud, S. (1917 [1915]-2001), Mourning and Melancholia, S.E. XIV, London, Vintage. 
Freud, S. (1930 [1929]), 'Civilization And Its Discontents' S.E. XXI, London, Vintage.

Freud, S. and Einstein, A. (1933 [1931]), 'Why War', in New Introductory Lectures on

Psycho-Analysis and Other Works, S.E. XXII, London, Hogarth Press.

Klein, M. (1987) 'The Psycho-analytic Play Technique: Its History and Significance', in Mitchell, J. (Ed) The Selected Melanie Klein, New York, The Free Press.

Klein, Melanie (2002) Love, guilt and reparation: and other works 1921-1945, Volume 1, New York, Simon and Schuster.

MacEoin, U. (1997) The IRA in the Twilight Years: 1923-1948, Dublin, Argenta Publications.

Maguire, J. (2004) 'Internment, the IRA and the Lawless Case in Ireland: 1957-61', Journal of the Oxford University History Society http://irishlabour.com/Irish MIlitant/Lawless Case.PDF, accessed 10/08/2014.

Robins, S. and Post, J. (1997) Political Paranoia: The Psychopolitics of Hatred, London, Yale University Press.

Post, J. (1986) 'Hostilité, Conformité, Fraternité: The Group Dynamics of Terrorist Behaviour', International Journal of Psychotherapy, Vol: 6, No: 2, pp, 211-224.

Post, J. (1998) 'Terrorist Psycho-Logic: Terrorist Behaviour as a Product of

Psychological Forces' in Reich, W. (Ed) Origins of Terrorism: Psychologies, Ideologies, Theologies, States of Mind, Washington, Woodrow Wilson Center Press.

Post, J. (2004) Leaders and Their Followers in a Dangerous World: The Psychology of Political Behaviour, Ithaca, Cornell University Press.

Post, J. (2005) 'Addressing the Causes of Terrorism', Psychology Working Group (Post. J, Chair) in The Club de Madrid Series on Democracy and Terrorism: Volume 1, the International Summit on Democracy, Terrorism and Security, Madrid, http://media.clubmadrid.org/docs/CdM-Series-on-Terrorism-Vol-1.pdf, 10/10/2009.

Post, J. (2007) The Mind of the Terrorist: The Psychology of Terrorism from the IRA to al-Qaeda, Basingstoke, Palgrave MacMillan.

Post, J. (2015) Narcissism and Politics: Dreams of Glory, Cambridge, Cambridge University Press.

Silke, A. (2003) 'Becoming a Terrorist' in Silke, A. (Ed) Terrorists, Victims and Society: Psychological Perspectives on Terrorism and its Consequences, Chichester, John Wiley \& Sons Ltd.

Thomson M. (2011) 'How De Valera asked UK to smear IRA chief Sean Russell', Document, Radio 4, 28th of March 2011, http://www.bbc.co.uk/news/world-12848272, accessed, 09/09/2014.

Uris, J and Uris, L. (1977) Ireland: A Terrible Beauty, London, Corgi Books.

Volkan, V. (1998) 'Transgenerational Transmissions and "Chosen Trauma”:

An Element of Large-Group Identity', Opening Address XIII International Congress International Association of Group Psychotherapy, August, 1998, http://www.vamikvolkan.com/Transgenerational-Transmissions-andChosen-Traumas.php, accessed 26/09/2014.

Volkan, V. (2007) 'Not Letting Go: From Individual Perennial Mourners to Societies with Entitlement Ideologies' in Fiorini, L., Lewkowicz, S. and Bokanowski, T. (Eds), On Freud's "Mourning and Melancholia," pp 90-109, 2007 Version, http://www.vamikvolkan.com/Not-Letting-Go\%3A-From-Individual-PerennialMourners-to-Societies-with-Entitlement-Ideologies.php, accessed 26/09/2014. 